\title{
Gendering Migration
}

DOI: $10.11567 / \mathrm{met} .30 .3 .4$

UDK: 314.7:305

Pregledni rad

Primljeno: 2. 2. 2014.

Prihvaćeno: 26. 12. 2014.

\section{Mirjana Morokvašić}

Institut des Sciences sociales du Politique, CNRS - Université Paris Ouest-Nanterre, Paris mirjana.morokvasic@u-paris10.fr

\begin{abstract}
SUMMARY
Migration patterns, migration discourse and underlying representations, migrants' experiences, obligations and duties as well as the expectations relative to their migration are gendered. Since the pioneering feminist migration scholars' questioning of men as a universal reference and the invisibility of women or their stereotypical representations as dependents in the mainstream production of knowledge on migration, the scholarship has evolved considerably. It is argued in the paper that the ongoing process of cross-fertilization of developments in two separate epistemologies, each initially questioning monolithic and essentialist visions of a "migrant" on one hand and a "woman" on the other, produced a fecund subfield of research "migration and gender". The paper provides an insight into this, reviewing work on the issues related to gendering different phases of migration. Bridging migration and gender brought to the top of research agendas issues that used to be on the margins, creating new visibilities but leaving out other gendered dimensions of complex realities of migrant experience.
\end{abstract}

KEY WORDS: migration, gender, representation, citizenship, family, impact of gender on migration, impact of migration on gender

\section{INTRODUCTION}

The conceptualizations of migration and mobility in research, but also by states and societies at large, have been along gendered lines. Migration patterns, migration discourse and underlying representations, migrants' experiences, obligations and duties as well as the expectations relative to their migration are gendered. Women and men not only engage in migrations and mobility differently, inducing differential impact on those who remain non-migrants, but their movements are better understood in the light of hegemonic/contesting femininities and masculinities. At the same time, gender identities are constitutive elements of other identities, cross-cutting other social relations of power with which they intersect. "Multiplicities 
of femininities and masculinities are recognized today as interconnected, relational and intertwined in relations of class, race-ethnicity, nation and sexualities" (Hondagneu-Sotelo, 2013: 233).

The centrality of gender can be traced back to the pioneering feminist migration scholars' questioning of men as a universal reference and the invisibility of women or their stereotypical representations as dependents in the mainstream production of knowledge on migration (Women in Migration, 1984; Morokvasic, 1983, 1984; Anthias, 1983; Gabaccia, 1994, among others). Since the reminder that the "Birds of passage are also women" (Morokvasic, 1984) the scholarship has evolved considerably (Donato et al., 2006; International Migration Review, 2006). It was an important stage towards acknowledging a need for a gendered perspective, which is increasingly shared today in migration research (International Migration Review, 2006) but also in policy making (Piper, 2003).

As Evelyn Nakano Glenn (1998: 3) argued "Gender gave us a terminology that enabled us to direct attention toward historical and cultural variability in meanings of womanhood and manhood". It is not just a characteristic of individuals, but an organizing principle of social structure. The focus in research on "women in migration" remains considerable (Miranda, 2008; Roulleau-Berger, 2010; Oishi, 2005) and while gender is often used as a "substitute" (Catarino and Morokvasic, 2005), or "a shorthand" for women (Green, 2012), it is usually analyzed in intersection with other dimensions of social relations and sources of inequality and discrimination. The intersectional frame, formulated by Patricia Hill Collins (1990) as interlocking systems of oppression constitutive of migration systems, coined by Crenshaw (1995), is an important tool with which we may more accurately identify the myriad intertwined forms of cultural privilege and oppression both before and beyond gender (Beloso, 2012). It has its roots in Black feminism, but in the European context a number of studies on the articulation of social divisions of power have been central in "paving the way" and enriching the debates: they called for contextualizing gender and drew attention to the simultaneity and articulation of gender with class, race or migrant status (Anthias and Yuval-Davis, 1983, 1992; Brah, 1996; Morokvasic, 1987 among others; in French see Kergoat, 2009; Cahiers du CEDREF, 2006). For further discussion mainly on the production of knowledge in English see Herrera (2013) and Anthias (2014).

Migration and gender (or vice versa) has been gradually constituted into a subfield of research, with recognition in academia, attracting scholars and students across different disciplines and fuelling an impressive amount of 
publications. ${ }^{1}$ This is a result of a slow but steady cross-fertilization of developments in two separate epistemologies, each initially questioning monolithic and essentialist visions of a "migrant" on one hand and "a woman" on the other. This is a process, the efforts to acknowledge and legitimize gender in immigration scholarship are ongoing and will be necessary as long as gender-blind migration studies exist or limit themselves to a lipservice inclusion of women.

Yet it is difficult to share fully the claim that indeed "vibrant scholarship" on gender and migration is "not reaching or reshaping some of the debates at the core" of the immigration scholarship, which remains androcentric and hermetically closed to feminist issues and gender (HondagneuSottelo, 2013: 233-234). One could argue instead that it is becoming a part of the core, reshaping migration scholarship by moving certain issues and questions away from the margins and creating new visibilities while, in turn, leaving others in the shadows.

The changing, or rather, as Nancy Green suggests "complementary" paradigms (2012) from the focus on men as a universal reference to women to gender have gradually brought new ways of understanding migration. The gender/intersectionality lens sheds new light on who goes and why, who will be denied the opportunity to move, who works and where, whose work is acknowledged as work, whose is invisible and unrecognized, how are gendered ways of life destabilized and reshaped in the process of migration, what are the repercussions of apparently gender neutral policies and so on. In this text the author provides a brief insight into the ongoing reshaping that bridges migration with women/gender, addressing some of the issues related to different phases of migration and framed by more general questions: how does gender affect outmigration, how are migration experience and practices gendered, what is the impact of migration on gender?

To Hondagneu-Sottelo's (2013) excellent review of ongoing efforts to acknowledge and legitimize gender in immigration scholarship in the US and elsewhere one could add many more from the myriad of publications in many languages, especially since 2000 . Below is just a selection of special issues of prime migration journals and a few handbooks, all carried out by renowned migration scholars in Europe and beyond: Willis, K. and Yeoh, B., Gender and Migration, Edward Elgar, 2000; Catarino, C., Morokvasic, M. and Hily, M-A. (eds), Femmes, genre, migration et mobilités, special issue of Revue européenne des migrations internationales, 2005 (21), 1; Andall, J. and Näre, L. (eds), Gendered Mobilities and Work in Europe, special issue of Journal of Ethnic and Migration Studies, 2013 (29), 6; Oso, L. and RibasMateos, N., The International Handbook on Gender Migration and Transnationalism, Edward Elgar, 2013; Piper, N. and Yamanaka K. (eds), Gender, Migration and Governance in Asia, special issue of Asian and Pacific Migration Journal, 2003 (12), 1-2. 


\section{GENDERING OUT-MIGRATION}

For a long time, an androcentric view prevailed in social sciences in general: in migration studies the assumption that the international migrant is a young economically motivated male, his experience assumed representative of all migrants irrespective of their gender, had overshadowed the diversity of migration streams, including those in which women outnumbered men. The conventional wisdom about feminization of migration today as a worldwide and recent phenomenon often directly or indirectly implies that migrations used to be exclusively male dominated in the past and that women did not participate otherwise than on the trail of migration of men. It took fifty years to acknowledge that in the overseas migration from Europe to the USA women outnumbered men already from the 1930s onwards (Houstoun, Kramer and Mackin Barrett, 1984). Meanwhile feminist historians uncovered the variety and the long-standing participation of women in migrations (Gabaccia, 1989; Moch, 1992; Harzig, 1997) and highlighted the complexities of the worldwide feminization (Donato et al., 2011).

In the gender-blind mainstream literature, the potential specificities of male and female migration were not expected to be of theoretical significance. The gendered distinction between "autonomous" and "family" migration (made habitually in the case of migration of women and seldom in the case of men), supports the assumption that patterns of female migration would either reflect those of male migration or that women are just passive followers/not real protagonists, and there is nothing to explain.

We learn from Ernest Ravenstein's Migration laws $(1885,1889)$ that distances matter and could differently impact on migration of women and men: women tend to outnumber men in short distances. Though his data collection and findings have been challenged lately, different accounts of rural to urban migration in $19^{\text {th }}$ and $20^{\text {th }}$ century Europe point to over-representation of women (Moch, 1992), whereas indeed most of international and especially overseas patterns were at first disproportionately male-dominated.

Moving away from both rational choice theories and structuralist approaches towards more integrative explanations of migration, focusing on the mediation between the individual migrant and the global economy through social networks, households (Boyd, 1989), migrant institutions (Goss and Lindquist, 1995) opened up a space for taking into account social context and social forces along with the economic ones. Scholars thus be- 
came more sensitive to causes underlying women as agents of migrations, as well as to all those that neither corresponded to the male homo economicus profile nor fitted the heterosexual normative frame.

Although the global framework in which migrations take place is the same for all, the specific dimensions - gender division of labour, spatial restrictions, property rights and access to capital as well as gender/age/class hierarchies in the sending areas, differently affect the potential migrants and refugees and determine who would be made available "ready-to-go" and who would remain.

In many societies men were expected to be the initiators of the moves. However, when women have better prospects for gainful employment, local norms restricting their mobility are challenged and targeted "migrantsto-be" are also women (Abadan-Unat, 1977; Morokvasic, 1987). They have meanwhile gained the reputation of being reliable in monetary remittances.

Beyond the flight from poverty and lack of occupational opportunities, the emigration, especially for all those whose gender practices do not fit the locally established gender norms, has often been an escape from the oppressive nature of the societies of origin (Jackson, 1984; Swaisland, 1993; Morokvasic, 1984, 1987). And yet precisely their spatial mobility can be in many ways restricted by the states and societies. The experience of lesbians (Falquet, 2012) or that of transgender hostesses (Parreñas, 2011) who escaped discrimination and the homophobic environment of their countries of origin, highlight as a "magnifying glass" the inherently transgressive character of migration of women.

Refugees are considered to be overwhelmingly female, women often being conflated in a category with children. Yet, as Jane Freedman argues, gender related persecutions and gendered asylum procedures affect women as well as men: men who escape hegemonic masculinities may as asylum claimants have to face the assumptions of being less "vulnerable" and more "threatening" than women. Still, women tend to be more negatively affected by gendered practices in the asylum process. They are a minority among asylum claimants, reflecting both gendered barriers which make it harder for them to leave their countries, as well as gender related risks of violence during their journey (Freedman, 2007). 


\section{GENDERED EXPERIENCE OF MIGRATION}

\section{Representations}

Racialized and gendered imaginaries by states and societies have always had an impact on mobilities and underlying policies.

Migration scholars in the past have often provided academic legitimacy to measures of inclusion and exclusion according to racial or ethnical categorizations, treating some immigrants as more desirable than others, more or less capable of getting assimilated into a nation. Representations of immigrants on these lines have been slow in changing but scholars have become more critical, rather than vehicling or spear-heading dominant representations. Gendered representations seem to be both shifting and resistant over time. The imaginaries relate mobility to men and maleness and sedentarity to women as preservers of hearth and home. So by crossing borders men especially in the $19^{\text {th }}$ and $20^{\text {th }}$ century industrialization era followed the gender norm of mobile family breadwinner, while women were seen as transgressing the norm unless they followed as dependents and remained invisible as active protagonists of migration. From the perspective of sending countries, when they are seen as transgressing local cultural expectations, migrant women may be subject to stigmatization and mobility restriction. Nana Oishi (2005) notes that some states in Asia tend to ban the out-migration of certain age categories of women into certain jobs. No such restrictions are known for men. Suspicion and fear targeted especially single women border crossers (Green, 2012), who were or could be stigmatized as prostitutes or potential prostitutes, their immigration jeopardized, or on the contrary, geared to accompany their male counterparts and their sexual needs (Hirata, 1979). Single middle class women from Britain, for whom emigration to the colonies was an escape from "personal frustrations and downward mobility", had to rely on intermediaries - "Emigration societies" - for sponsorship and protection (Swaisland, 1993: 159).

Gendered categories of work are socially constructed with underlying assumptions about "natural" suitability of either men or women for specific jobs. The emblematic figure of a migrant has for a long time been a male industrial worker and men were recruited into jobs designated as male. The demand for domestic and care-workers shifted the focus to women considered naturally gifted and generally charitable in disposition, undemanding and subservient, i.e. perfectly suited for service and care work (Lyon, 2006). The female domestic/care worker is one of the emblematic figures, which dominate our understanding of the new global migrations 
nowadays: the other is no longer the male factory worker but the IT specialist. According to Eleonore Kofman who is among the scholars making this distinction, this reinforces the paradigmatic separation between the highly skilled male and the less-skilled female. While the IT specialist is privileged in the knowledge economy and benefits from more favourable immigration regulations, the domestic and care-worker, "though indispensable to the well-being and social reproduction of society, is equated with embodied knowledge and skills, with little potential for an increase in human capital and therefore poorly valued and remunerated" (Kofman, 2013: 595).

The combination of gender, migrant status and racialized characterizations as rationales for employment of specific groups is not fixed; it can adjust over time and in different places. It can differ even within the same firm: Carolina Bank Muñoz shows how the management of a transnational firm producing tortillas uses a gender discourse as a rationale for employing mainly women in its Mexico branch but relies on an immigration logic in its US branch, where a majority of workers doing the same job are Mexican immigrant men (Bank Muñoz, 2008). Recent research on men in domestic and other work defined as "female" contributes to better understanding of the negotiations at stake for (re)construction of masculinities (Kilkey, 2010; Scrinzi, 2013). Miriam Glücksman (2010) argued that when immigrant men are recruited in stereotypically women's jobs rationalized as requiring nimble fingers and dexterity, the rationale shifts to strength, hard work and reliability to fit the required attributes of immigrant men.

Women constitute a majority of those who enter receiving states as families and have been perceived "naturally" within the family frame. Depending on intersecting imaginaries of gender, race, ethnicity or migrant origin, families could be seen either as a stabilizing force and tool of assimilation, but also as reinforcing traditional values and as obstacles to assimilation or integration (Guerry, 2013). Building on the analysis of parliamentary discussions and in-depth interviews in Germany, Laura Block has recently shown how discourse on spousal migration, which allegedly causes integration deficit and produces women as victims, is used to justify restrictions on family reunification in Germany and beyond (Block, 2014). As for men who enter as "family migrants", they are more likely than women to face suspicious allegations of trying to circumvent entry barriers and contract marriages of convenience.

Migration scholars are, more than ever before, constantly confronted today with abundant production of knowledge in the venues other than academia, which relies on gendered and racial stereotyping to produce the 
image of the migrant "other", leaving in the shadows multiple and complex realities of migrant experience. This creates hyper-visibility of certain issues and allegation of gender inequalities related to culture, while invisibilizing other instances of gender-, class- and migrant status-related inequalities. Focus on issues such as forced marriages, honour killings, polygamy, Islamic headscarves and trafficking produces gendered victimization (of women) and relates it to the "cultural tradition of Islam" and to violence and insecurity, spear-headed by "patriarchal migrant masculinities" as formulated by Paul Scheibelhofer (2013) in his insightful analysis of migrant Turkish Muslim masculinities in Austria. Venturing into, and for different reasons, prioritizing the issues that are at the top of the public discourse agendas, the research risks reiterating (and does so, in fact) rather than questioning the produced visibilities and invisibilities (for further discussion see Morokvasic, 2011; Kosnick, 2010), leaving in the shadows complex realities of the migrants' experience and other forms of inequality and exclusion, in particular those related to limited access to and opportunities on the labour market. Using the example of transnational families and the way research has taken for granted the heteronormative frame, Kira Kosnick (2014) forcefully demonstrates how the underlying gendered assumptions about the primacy and legitimacy of biological families and essentializing women's nurturing role are taken for granted, while other forms of affective bonds and non-normative relationships in the migration process remain underestimated.

The imaginaries about migration and migrants are extremely important in understanding not only their impact on policies, but also the ways we conduct research.

\section{Citizenship}

Stephen Castles and Alastair Davidson (2000) explore citizenship in the age of globalization. Reminding us that women have been excluded from formal citizenship until fairly recently, and that minority women's exclusion from citizenship is brought about through discourses and practices in which gender, racialization and class are interlocked, they argue that the theory of citizenship for a global society must be based on the separation of the nation and the state. In a world where being here and there becomes possible or the only possible modus vivendi for those who reconcile transmigration and citizenship, other forms of inclusion than those confined to and defined by a national frame have become a part of their everyday practice (Tarrius, 1992; Tarrius, Missaoui and Qacha, 2013). Political engagements 
across borders, multiple loyalties and citizenships are contemporary realities. The transnational perspective (Glick Schiller, Basch and Szanton-Blanc, 1995) challenged the static view of migration as a discrete, one-way movement from one location to another and opened up new areas for research in migration studies. It enabled one to look beyond the immigration society and state as a normative frame into mobilities, connections and belongings in transnational social spaces. Yet much of the scholarship on transnational citizenship, especially in its early stages, has been gender-blind.

Feminist discussions on citizenship, sensitive to ethnicity, nationality and class related differences and inequalities (Anthias and Yuval-Davis, 1989; Yuval-Davis, 1999; Kofman, 1995) have often remained within the nation-state frame, namely that of the state of reception. Their focus on legal citizenship highlights the exclusion of women, perceived by the states as bearers and reproducers of the nation. Linda Guerry's (2013) historical analysis of immigration and naturalization in France depicts different moments and practices geared by demographic and assimilationist concerns by which French women became non-citizens if they married a foreigner, while foreign women became automatically French through marriage, but still ran the risk of being stripped of their new status. Recent work gendering migrant citizenship, based on in-depth interviews and participant observation, shows how mobility or the impossibility of being mobile are crucial in constructing citizenship in a transnational migratory space, both in terms of status and practices. Umut Erel (2009), focusing on migrant women from Turkey in Germany and the UK, views gender and ethnicity as social locations that mutually constitute each other and takes migrants' agency as a starting and central point to demonstrate how these women outsiders to the nation create new meanings of belonging. Kyoko Shinozaki (2015) observes Philippine domestic workers in Germany and uses a transnational and gender lens to conceptualize their "migrant citizenship from below", highlighting transnational embeddedness as well as migrants' agency in face of policies from above that construct their status. Rhacel Salazar Parreñas in her analysis of the indentured mobility of Filipina hostesses in Japan shows that the conditions of their inclusion and membership in Japanese society vary, depending on their subject position as long-term residents, temporary contract workers or undocumented workers. She coined the expression "sexual citizenship" to underscore that stable residency as a way of belonging to Japanese society is conditioned for Filipinas by sexual relations with Japanese citizens. By calling attention to wives and mothers as sexual citizens, she argues that "the responsibility of reproducing populations is a constitu- 
tive element of citizenship, a condition only magnified in the situation of entertainers who want long-term residency in Japan" (Parreñas, 2011: 179). She also highlights the dependency that thus gained legal status is conditioned upon and the vulnerabilities it entails.

\section{Work}

In the early phases of gendering migration the focus on the labour market initially had the purpose of making women and their often informal and undocumented work visible (Phizacklea, 1983; Anthias, 1983: Morokvasic, 1983, 1993). It was necessary in the context in which the emblematic figure of the migrant was the male factory worker, while women were treated as dependents, their work invisible and unrecognized as work. The gendered nature of the discourse reflects itself in expressions like "migrant workers and their families" where the productive/reproductive divide assumes the worker to be a man and places women with children in ("non-productive") families, sometimes lumping them together in statistical records.

Gendered and racialized attributes and representations combined act as rationales for employing most migrants in precarious, low-paid jobs in agriculture, construction, manufacturing and service jobs, mostly domestic work, nursing and care-giving. Domestic service, considered to be the biggest employer of immigrant women, is increasingly providing jobs for men as well. Almost three decades after Claude Meillassoux's (1975) powerful demonstration about the importance for the capital to have the household and its reproductive labour preserved and available, the conceptualization of female migration as "global care chains" (Ehrenreich and Hochschild, 2002; Parreñas, 2001) resets the argument within a transnational frame and in the processes of global inequalities (Herrera, 2013).

Migrants replace both unpaid and paid labour of women in countries where increasing local female employment rates and aging population have created a demand in a "domestic niche" (Lutz, 2008). Their employment is framed by the inadequacy of welfare regimes and, in terms of migration policies, by the absence of legal immigration channels, sometimes compensated by toleration of informal inflows and circulatory patterns (Finotelli and Sciortino, 2006). The shift to a "migrant-minder" model creates new nationality- and class-based divisions between local women and women who are non- or new-EU nationals, who take over cleaning and caring work. Parreñas (2008) sees in the force of domesticity, i.e. persistence of the ideology considering women to be those most apt to care for their families, the source of resistance of families and nation states to full recognition of 
domestic work outsourced to foreigners as labour deserving fair wages and legal residency.

While the sector of domestic work and care has been in the focus of attention of much of the research in the field of migration and gender (Anderson, 2000; Andall, 2000; Metz-Göckel, Morokvasic and Senganata Münst, 2008; Lutz 2008, 2011; Lutz and Palenga-Möllenbeck, 2011; Triandafyllidou, 2013), other issues related to migrants' incorporation into the labour market remain understudied, like skilled migration (Kofman, 2000, 2013), migrants' mobilisation (Schwenken, 2006), and work in other economic sectors or self-employment (Morokvasic, 1991). The recent insight into a variety of gendered mobilities and work in Europe provided in the special issue of the Journal of Ethnic and Migration Studies (2013), coordinated by Jacqueline Andall and Lena Näre, is in that respect exceptional.

Jacqueline Andall (2013) observes different patterns of incorporation for women and men in agriculture, another sector extensively employing migrant labour. Itinerant mobility as practiced by male harvest pickers or their shifting to other short-term jobs, is problematic for women. They are more likely to join established programmes like the EU-sponsored one for strawberry pickers from Morocco to Spain, where specific gender profiling restricts access to work to mothers who have left their children in their home country. This successfully ensures circularity and prevents settlement, nondesirable for third country nationals.

The issue of sex work has not been much in the focus of migration research with the exception of the IOM sponsored studies approaching it through the prism of trafficking and seeing migrants as naïve, coerced victims. The feminist debate on the issue is split between those (mainly radicalabolitionists) for whom prostitution represents the paradigmatic form of domination of women by men - whereby they miss men as sex-workers and marginalize other sources of power relations - and others who view it as any other economic activity, considering gender inequality inextricable from class, race and other intersected inequalities. For further discussion on sex work and feminism see Beloso (2012).

In the context of restrictive immigration policies, the sector of entertainment and prostitution, marked by a persisting demand, is sometimes the only available "gate opener" to the labour market. Entering such a stigmatized activity can neither be explained by "coercion" nor as resulting from a "free choice", but reflects migrants' adaptive action under constraints in a context marked by economic need, legal restrictions regarding mobility, oppressive gender relations and gendered standards of morality (Thiévent, 
2010; Parreñas 2011; Oso Casas, 2009). Access to a legal status and residency in their own right, rather than as a sign of settlement, represents an essential element of sex workers' mobility capital. It remains out of reach as long as they are not considered as autonomous economic migrants, remain tied to the same employer or derive their limited rights either as a family member (through marriage) or as a recognized "victim of trafficking" (Catarino and Morokvasic, 2013). In her analysis of the indentured mobility of Filipino migrant hostesses in Japan, female and transgender, Rhacel Salazar Parreñas (2011) forcefully argues against the dominant discourse on human trafficking and its policy solutions to "rescue the victims", based on generalizations and missing the specificities of migrants' lives.

\section{Family}

While family migration is a hidden avenue to the labour market, the often made distinction between family and autonomous migration (in the case of women) discursively assigns families to a status of dependents. As such they represent ideal labour for ethnic economies where men and women work together preserving gender hierarchies. The provision of cheap and/ or unpaid labour from within a family or community and the mobilisation of ethnic networks is an essential resource and a key competitive advantage in ethnically run motel businesses, garment manufacturing or the food sector (Anthias, 1983; Phizacklea and Ram, 1996; Assar, 1999; Morokvasic, 1993).

Migrations separate people, migrant families have always been stretched across borders. As such they only recently attracted scholarly attention in the receiving states. In the sending countries, in contrast, there has been an early concern about emigrant families and the social costs of migration. Women's migration has generally been identified as being more problematic for families than that of men (Asis, 1995), being blamed for "disrupting" the social and gender order. Abadan-Unat (1977) notes that at the start of Turkey's large external migration, there were constant requests addressed by Turkish workers to government representatives to prohibit women from leaving their country for work. Public outcry about disintegration of bilocated or incomplete families in connection with guestworkers from socialist Yugoslavia leaving their children behind did not find much confirmation in research, except in cases when the emigrant was the mother (Katunarić, 1978). Parallels can be found today: from the Philippines to India, from Moldova to Poland; the public blame targets primarily migrant women family bread-winners. As Chiho Ogaya (2004) observed, the most sensa- 
tional social cost of migration, "disruption of the family" is always referred to through the absence of the mother and the destruction of gender norms.

In the scholarship of the receiving states, the interest in immigrant families was closely linked to public concern about them as either obstacles or vehicles of integration into the receiving society. Children and spouses left behind, remittances and their use, legislation restricting family reunification or facilitating it, were issues addressed within labour migration studies production which, with few exceptions, treated families as a marginal issue.

Renewed interest in migrant families in recent years and a spectacular proliferation of literature on transnational families, especially from the late 1990s onwards, can be placed at the cross-roads of epistemological developments in both migration and gender studies. Herrera (2013: 479) sees it as a result of increasing interest in both transnational practices and the "care drain" argument raised by the global care chain concept.

Bryceson and Vuorella (2002) define transnational families as those living some or most of the time separated from each other, yet holding together and contributing to the feeling of collective welfare and unity, a "familyhood" across the borders. The importance of mobility capital for transnational families is stressed by a number of studies: thus, free circulation beyond the nation-states that transnational family dispersal covers becomes a condition for their right to family life (Razy and Baby-Collin, 2011), which in turn, is considered as one of milestones of integration. Studies focusing at first on transnational mothering, followed by those on transnational parenting, indicate the ways families practice living-apart-together and the contradictions and tensions they are confronted with when family care obligations have to be solved at a distance (Hondagneu-Sottelo and Avila 1997; Kuzma, 2012). They highlight maintenance or break-up of emotional links, the nature of decision-making processes and are witness to disruption or reproduction of power hierarchies.

\section{IMPACT OF MIGRATION ON GENDER}

How migration impacts on social change and how are gender hierarchies shaken or preserved have been challenging questions to many scholars. With the exception of some recent studies, most of the existing research has traditionally focused on women within a heterosexual normative frame.

Although many studies insist on both gains and losses (Tienda and Booth, 1991; Pessar and Mahler, 2003; Rouleau-Berger, 2010), the conventional wisdom has been that a woman's bargaining power and autonomy 
increases in migration. Despite gender inequities in the workplace, immigrant women generally gain greater personal autonomy, whereas men lose ground (Foner, 1978), as their low occupational status does not translate into public recognition. Women also tend to be reluctant returnees (Grassmuck and Pessar, 1991; Morokvasic, 1987; Fibbi, Bolzmann and Vial 1999), feeding into the assumption that they are better off where they are now, more favourable to settlement and more adaptable as opposed to men. Working in Spain enables Moroccan women greater access to and control over resources and provides them with more autonomy in managing their lives "in spite of the inferiority of their position in Spain both as foreigners and women" (Ramírez, 1999: 35). Thus, being a woman becomes an advantage: crossing borders, getting jobs, confronting obstacles (visas, customs officers) may sometimes be easier for women. In turn, as Spain's immigration policy gives priority to female immigrants over their male counterparts, it contributes to changing expectations related to gender order in Morocco: men are no longer seen as exclusive economic providers for the family as women enter the sphere as indispensable economic agents.

The gender power relations are also reconfigured by the out-migration of young women for work or marriage purposes as in Kerala (Percot, 2005) or South Vietnam (Bélanger and Linh, 2011). Their status is enhanced, giving them and their families more bargaining power in marriage transactions resulting in an increased preference for having girls rather than boys in the sending villages. In contrast, for many single men who remain back in villages, getting married becomes difficult due to the perceived greater value of foreign men, higher bride-prices and a shortage of potential brides.

Sex work and strategic use of sexuality can be a springboard to reverse downward mobility in migration as observed by Florence Lévy and Marylène Lieber $(2008,2009)$ in the case of North Chinese women in France, where processes of legal, ethnic and gender segregation have relegated them to devalorized sectors of the economy. In the similar vein, Rhacel Salazar Parreñas argues that Philippine hostesses-entertainers are labour migrants, who see their migration as empowering and liberating: while they acquire decision-making power and respect of their kin as breadwinners, practicing "commercial flirtation also sexually liberates them, allowing them to challenge conservative norms that limit acceptable sexual activities of women" (2011: 273).

However, many accounts stress the opposite side, including: strengthening of traditional roles, dependency, the increased work load due to loss of a support network and decrease in earning power as in the case of the 
highly skilled Hong Kong Chinese women in Canada (Man, 1995). And when, as in the case of Cuban immigrants to the US or Eastern Europeans in post-communist migrations, employment is treated as a mere "family obligation" for women, not likely to bring about changes in male-female relationships (Ferree, 1979; Kalwa, 2008).

The outsourcing of domestic tasks to migrants contributes to equal opportunities between local men and women in the labour market, but at the same time enhances inequalities among women. It also enables gender hierarchies to be preserved both in employers' and in migrants' transnational households (Oso, 2003; Lutz, 2008; Kuzma, 2012). Back in the home country, gender order reasserts itself and women have fewer opportunities to make use of their success, confronted with the stigma of bad reputation (Potot, 2005).

This contradictory empirical evidence suggests that processes of reproduction of gender order are manifest in/parallel to the situations of apparent reversal. At the same time and in line with Patricia Pessar's (1984) observation that the deeply rooted gender identities are not openly challenged but rather redefined within the pressures and requirements of the intersecting power hierarchies in the context of migration, they contain elements of change, of subversion from within (Morokvasic, 2007).

The author's argument here is that migrants tend to use the traditional gender order and rely on it for their own projects of self-realisation, autonomy, empowerment or simply upward mobility for themselves or benefit of the family, or to resist other dominations and power hierarchies (related to class, race or migrant status).

Resorting to matrimonial strategies in order to obtain stable residence (Giabiconi, 2005), opens up opportunities for self-employment and business creation and doors for reuniting the remaining family members. Traditional norms and institutions can also be reconfigured and instrumentalized. However, rather than calling into question the institution of arranged marriages or the dowry system, Kerala nurses who migrated to Gulf states (Percot, 2005) or young Sikh women in Britain (Bhachu, 1991) combined their desire for autonomy and use dowries to "earn their husbands" and start nuclear families, thus emancipating themselves from their fathers and brothers. The capital earned by Tunisian women on their trading trips to Italy (Schmoll, 2005) is invested both in their daughters' dowries, but also in their education. Thus, mothers are dealing with the contradiction between preserving some gender norms intact while trying to promote emancipation of their daughters. 
Migration provides exit and opportunities for struggle and resistance for those who do not fit into the hegemonic femininities and masculinities of their milieu of origin. Escape (or "exit" in Hirschman's sense /1970/) from it is a form of struggle, but becomes also a resource, a possibility to support the family and in return, regain respect and recognition (Morokvasic, 1987, 2004). Some take advantage of attributions that initially handicap them, and reinvest gender roles with new attributes and qualities in line with their own migration practices (Cvajner, 2011). Moldova women working in Turkey depicted as irresponsible because of their being "absent mothers and immoral wives", do not question the boundaries of the local norm of such motherhood as the key to the social order, but instead stretch them to include migrant mothers, not only to justify their absence but to reassert themselves as better mothers than those who do not migrate (Keough, 2006).

When men get employment in the domestic service sector and care, i.e. in what is seen as "naturally" women's work, they have to qualify for the highly gendered requirements for the job. Thus, being capable of "working like a woman", is a strong argument in negotiating employment. With time in the job they reinvest their present role of a male domestic worker with "naturally male" attributes, putting them forward as their competitive advantage: for instance, physical strength - indeed a necessary quality for the job but rarely taken into account when the performers of caring and domestic tasks are women (Scrinzi, 2005, 2013). Male immigrants working in what they view as either being women's or lower class jobs in London hotels and hospitals renegotiate their masculinities. They are either flexible with their economic identity while contesting their gender identities, or they are strategically flexible with their gender identities in order to perform according to expected economic family obligations (Batnitzky, McDowell and Dyer, 2009).

\section{IN LIEU OF CONCLUSION: NEW VISIBILITIES, REMAINING GAPS}

Migration and gender is no longer just a "conference catchword" (Green, 2012). It has grown into a subfield of research, with recognition in academia and a prolific production of knowledge worldwide to which this selective overview cannot do justice. It is a result of gradual cross-fertilization of developments in two separate epistemologies, each initially questioning monolithic and essentialist visions of a "migrant" on one hand and "a 
woman" on the other. This is an ongoing process, re-shaping enquiries in both migration and gender studies. While gender-blind migration studies no doubt still exist, gender perspective provides new insights in our understanding of migration processes and migrants as actors in them. Some dimensions that would have been marginal research objectives some time ago are now at the top of research agendas: domestic and care workers, "servants of globalization" as Parreñas (2001) called them, their emotions and subjectivities, transnational families and their living-apart-together, as well as citizenship from below. The new visibility of some of these issues as well as the overwhelming focus on gendered "victims" in the production of knowledge outside of academia, has to be appreciated against gaps in research and lack of visibility of other gendered forms of inequality and exclusion in particular in the labour market, as well as migrants' mobilities and mobilizations to overcome them that have received little attention so far.

Acknowledgement: The author would like to thank the anonymous reviewers for their insightful comments.

\section{REFERENCES}

Abadan-Unat, N. (1977). Implications of Migration on Emancipation and Pseudoemancipation of Turkish Women, International Migration Review, 11 (1): 31-57.

Andall, J. (2000). Gender, Migration and Domestic Service. Aldershot: Ashgate.

Andall, J. (2013). Gendered Mobilities and Work in Europe: An Introduction, Journal of Ethnic and Migration Studies, 39 (4): 525-534, doi: 10.1080/1369183X.2013.745229.

Anderson, B. (2000). Doing the Dirty Work? The Global Politics of Domestic Labour. New York: Zed Books.

Anthias, F. (1983). Sexual Divisions and Ethnic Adaptation: The Case of Greek-Cypriot Women, in: A. Phizacklea (ed.). One Way Ticket: Migration and Female Labour. London: Routledge and Kegan Paul, 73-94.

Anthias, F. (2014). Beyond Integration: Intersectional Issues of Social Solidarity and Social Hierarchy, in: F. Anthias and M. Pajnik (eds). Contesting Integration, Engendering Migration. Basingstoke: Palgrave Macmillan, 13-36.

Anthias, F. and Yuval-Davis, N. (1983). Contextualizing feminism - gender, ethnic and class divisions, Feminist Review, 15: 62-75.

Anthias, F. and Yuval-Davis, N. (eds) (1989). Woman - Nation - State. London: Macmillan. Asis, M. (1995). Family Ties in a World without Borders, Philippine Sociological Review, 42: 16-26. 
Assar, N. N. (1999). Immigration Policy, Cultural Norms, and Gender Relations among Indian-American Motel Owners, in: A. G. Kelson and D. L. DeLaet (eds). Gender and Immigration. Basingstoke: Macmillan, 82-102.

Bank Muñoz, C. (2008). Transnational Tortillas: Race, Gender, and Shop-Floor Politics in Mexico and the United States. Ithaca: Cornell University Press.

Batnitzky, A., McDowell, L. and Dyer, S. (2009). Flexible and Strategic Masculinities: The Working Lives and Gendered Identities of Male Migrants in London, Journal of Ethnic and Migration Studies, 35 (8): 1275-1293, doi: 10.1080/13691830903123088.

Bélanger, D. and Tran, G. L. (2011). The impact of transnational migration on gender and marriage in sending communities of Vietnam, Current Sociology, 59 (1): 59-77, doi: $10.1177 / 0011392110385970$.

Beloso, B. M. (2012). Sex, Work and the Feminist Erasure of Class, Signs: Journal of Women in Culture and Society, 38 (1): 47-70, doi: 10.1086/665808.

Bhachu, P. (1991). Culture, Ethnicity and Class among Pundjabi Sikh Women in 1990s Britain, New Community, 17 (3): 401-412.

Block, L. (2014). On Female Victims and Parallel Worlds: Gender and Ethnicity in Policy Frames of Spousal Migration in Germany, in: F. Anthias and M. Pajnik (eds). Contesting Integration, Engendering Migration. Basingstoke: Palgrave Macmillan, 242-260.

Boyd, M. (1989). Family and Personal Networks in International Migration: Recent Developments and New Agendas, International Migration Review, 23 (3): 638-671.

Brah, A. (1996). Cartographies of the Diaspora. London: Routledge.

Bryceson, D. and Vuorela, U. (eds) (2003). The Transnational Family: New European Frontiers and Global Networks. Oxford, UK: Berg.

Cahiers du CEDREF (2006). (Ré)articulation des rapports sociaux de sexe, classe et « race » (eds J. Falquet, E. Lada and A. Rabaud), 14.

Castles, S. and Davidson, A. (2000). Citizenship and Migration: Globalization and the Politics of Belonging. Basingstoke: Macmillan Press.

Catarino, C. and Morokvasic, M. (2005). Femmes, genre, migration et mobilités, Revue européenne des migrations internationales, 21 (1): 7-27.

Catarino, C. and Morokvasic-Müller, M. (2013). Blurred lines: Policies and experience of migrant women in prostitution and entertainment, in: F. Anthias, M. Kontos and M. Morokvasic-Müller (eds). Paradoxes of Integration: Female Migrants in Europe. Dordrecht - London: Springer, 153-172.

Collins, P. H. (1990). Black Feminist Thought. London: Harper.

Crenshaw, K. W. (1995). Mapping the Margins: Intersectionality, Identity Politics, and Violence against Women of Color, in: K. Crenshaw et al. (eds). Critical Race Theory. New York: New Press, 357-383.

Cvajner, M. (2011). Hyper-femininity as decency: beauty, womanhood and respect in migration, Ethnography, 12 (3): 356-374, doi: 10.1177/1466138110392463.

Donato, K., Alexander, J., Gabaccia, D. and Leinonen, J. (2011). Variations in the gender composition of immigrant populations: how they matter, International Migration Review, 45 (3): 495-526

Donato, K., Gabaccia, D., Holdaway, J., Manalansan M. M. and Pessar, P. (2006). A glass half full? Gender in migration studies, International Migration Review (Gender and Migration Revisited, eds D. Gabaccia et al.), 40 (1): 3-26. 
Ehrenreich, B. and Hochschild, A. R. (2003). Global Woman: Nannies, Maids and Sex Workers in the New Economy. London: Granta.

Erel, U. (2009). Migrant Women Transforming Citizenship: Life Stories from Britain and Germany. Farnham: Ashgate.

Erel, U., Morokvasic, M. and Shinozaki, K. (2003). Introduction: Bringing Gender into Migration, in: M. Morokvasic, U. Erel and K. Shinozaki (eds). Crossing Borders and Shifting Boundaries. Vol. I: Gender on the Move. Opladen: Leske + Budrich, 9-22.

Falquet, J. (2012). Lesbiennes migrantes, entre hétéro-circulation et recomposition néoliberales du nationalisme, in: C. Cossée et al. (eds). Le genre au cour des migrations. Paris: Editions Pétra, 123-145.

Ferree, M. M. (1979). Employment without Liberation: Cuban Women in the United States, Social Science Quarterly, 60 (1): 35-50.

Fibbi, R., Bolzmann, C. and Vial, M. (1999). Italiennes et Espagnoles en Suisse à l'approche de l'âge de la retraite, Revue européenne des migrations internationales, 15 (2): 69-94.

Finotelli, C. and Sciortino, G. (2006). Looking for the European soft underbelly: visa policies and amnesties for irregular migrants in Germany and in Italy, in: S. Baringhorst, J. F. Hollifield and U. Hunger (eds). Herausforderung Migration Perspektiven der vergleichenden Politikwissenschaft. Berlin: Lit, 249-279.

Foner, N. (1978). Jamaica Farezell: Jamaican Migrants in London. Berkeley: University of California Press.

Freedman, J. (2007). Gendering the International Asylum and Refugee Debate. Basingstoke: Palgrave Macmillan.

Gabaccia, D. (1989). America's immigrant women: a review essay, Journal of American Ethnic History, 8 (2): 127-133.

Gabaccia, D. (1994). From the Other Side: Women, Gender \& Immigrant Life in the U.S., 18201990. Bloomington: Indiana University Press.

Giabiconi, D. (2005). Les mariages mixtes franco-polonais : contours et enjeux, Revue européenne des migrations internationales, 21 (1): 259-273.

Glenn, E. N. (1998). Gender, Race and Classe. Bridging the Language-Structure Divide, Social Science History, 22 (1): 31-38.

Glick Schiller, N., Basch, L. and Szanton-Blanc, C. (1995). From immigrant to transmigrant: theorizing transnational migration, Anthropological Quarterly, 68 (1): 48-63.

Glücksman, M. (2010). Les plats cuisinés et la nouvelle division internationale du travail, in: J. Falquet et al. Le sexe de la mondialisation : genre, classe, race et nouvelle division $\mathrm{du}$ travail. Paris: Presses de la Fondation Nationale des Sciences Politiques, 85-98.

Goss, J. D. and Lindquist, B. (1995). Conceptualizing International Labor Migration: A Structuration Perspective, International Migration Review, 29 (2): 317-351.

Grassmuck, S. and Pessar, P. R. (1991). Between Two Islands: Dominican International Migration. Berkeley: University of California Press.

Green, N. L. (2012). Changing Paradigms in Migration Studies: From Men to Women to Gender, Gender \& History, 24 (3): 782-798, doi: 10.1111/j.1468-0424.2012.01706.x.

Guerry, L. (2013). Le genre de l'immigration et de la naturalisation. Lyon: ENS éditions.

Harzig, C. (ed.) (1997). Peasant Maids, City Women: From the European Countryside to Urban America. Ithaca: Cornell University Press. 
Herrera, G. (2013). Gender and International Migration: Contributions and CrossFertilizations, Annual Review of Sociology, 39: 471-489, doi: 10.1146/annurevsoc-071811-145446.

Hirata, L. C. (1979). Free, Indentured, Enslaved: Chinese Prostitutes in NineteenthCentury America, Signs: Journal of Women in Culture and Society (Women in Latin America), 5 (1): 3-29.

Hirschman, A. O. (1970). Exit, Voice and Loyalty: Responses to Decline in Firms, Organizations and States. Cambridge: Harvard University Press.

Hondagneu-Sottelo, P. (2013). New directions in gender and immigration research, in: L. Oso and N. Ribas-Mateos (eds). The International Handbook on Gender, Migration and Transnationalism: Global and Development Perspectives. Cheltenham: Edward Elgar, 233-245, doi: 10.4337/9781781951477.00020.

Hondagneu-Sotelo, P. and Avila, E. (1997). "I'm here, but I'm there": the meanings of Latina transnational motherhood, Gender and Society, 11 (5): 548-71, doi: 10.1177/089124397011005003.

Houstoun, M., Kramer, R. G. and Mackin Barrett, J. (1984). Female Predominance of Immigration to the United States Since 1930: A First Look, International Migration Review, 18 (4): 908-963.

International Migration Review (1984). Women in Migration (special issue), 18 (4).

International Migration Review (2006). Gender and Migration Revisited (special issue) (eds D. Gabaccia et al.), 40 (1).

Jackson, P. (1984). Women in 19th Century Irish Emigration, International Migration Review, 18 (4): 1004-1020.

Journal of Ethnic and Migration Studies (2013). Regimes of Mobility: Imaginaries and Relationalities of Power (special issue) (eds J. Andall and L. Näre), 39 (4).

Kalwa, D. (2008). Commuting between private lives, in: S. Metz-Göckel, M. Morokvasic and A. Senganata Münst (eds). Migration and Mobility in an Enlarged Europe: A Gender Perspective. Leverkeusen: Barbara Budrich, 121-140.

Katunarić, V. (1978). Vanjske migracije i promjene u porodici [International migration and changes in family]. Zagreb: Centar za istraživanje migracija.

Keough, L. J. (2006). Globalizing 'Postsocialism': Mobile Mothers and Neoliberalism on the Margins of Europe, Anthropological Quarterly, 79 (3): 431-61.

Kergoat, D. (2009). Dynamique et consubstantialité des rapports sociaux, in: E. Dorlin (ed.). Sexe, race, classe : pour une épistémologie de la domination. Paris : PUF, 111-125.

Kilkey, M. (2010). Men and domestic labor: a missing link in the global care chain, Men and Masculinities, 13 (1): 126-149, doi: 10.1177/1097184X10382884.

Kofman, E. (1995). Citizenship for some and not for others: spaces of citizenship in contemporary Europe, Political Geography, 14 (2): 121-137.

Kofman, E. (2000). The invisibility of skilled female migrants and gender relations in studies of skilled migration in Europe, International Journal of Population Geography, 6 (1): 45-59, doi: 10.1002/(SICI)1099-1220(200001/02).

Kofman, E. (2013). Gendered Labour Migrations in Europe and Emblematic Migratory Figures, Journal of Ethnic and Migration Studies, 39 (4): 579-600, doi: 10.1080/1369183X.2013.745234. 
Kosnick, K. (2014). Mediating Migration: New Roles for Mass Media, InMedia: the French Journal of Media and Media Representations in the English-Speaking World, 5 (published online 17 September 2014), http://inmedia.revues.org/761.

Kosnick, K. (2010). Sexuality and Migration Studies: The Invisible, the Oxymoronic and Heteronormative Othering, in: H. Lutz, M. T. Herrera Vivar and L. Supik (eds). Framing Intersectionality: Debates on a Multi-Faceted Concept in Gender Studies. Farnham: Ashgate, 121-135.

Kuzma, E. (2012). Emergence d'une communauté transnationale dans l'espace migratoire européen. Analyse de la migration polonaise à Bruxelles (2002-2009) (thèse de doctorat). Bruxelles: Université Libre de Bruxelles.

Lévy, F. and Lieber, M. (2008). Northern Chinese women in Paris: the illegal immigration - prostitution nexus, Social Science Information, 47 (4): 629-642, doi: $10.1177 / 0539018408096451$.

Lévy, F. and Lieber, M. (2009). La sexualité comme ressource migratoire : les Chinoises du Nord à Paris, Revue française de sociologie, 50 (4): 719-746.

Lutz, H. (2008). Migration and Domestic Work: a European Perspective on a Global Theme. Aldershot: Ashgate.

Lutz, H. (2011) The New Maids: Transnational Women and the Care Economy. London: Zed Books.

Lutz, H. and Palenga-Möllenbeck, E. (2011). Care, gender and migration: towards a theory of transnational domestic work migration in Europe, Journal of Contemporary European Studies, 19 (3): 349-364, doi: 10.1080/14782804.2011.610605.

Lyon, D. (2006). The Organization of Care Work in Italy: Gender and Migrant Labor in the New Economy, Indiana Journal of Global Legal Studies, 13 (1): 207-224, doi: 10.2979/ GLS.2006.13.1.207.

Man, G. (1995). The Experience of Women in Recent Middle-Class Chinese Immigrant Women from Hong Kong: An Inquiry into Institutional and Organizational Processes, Asian and Pacific Migration Journal, 4 (2-3): 303-325.

Meillassoux, C. (1975). Femmes, greniers et capitaux. Paris: Maspero.

Metz-Göckel, S., Morokvasic, M. and Senganata Münst, A. (eds). (2008). Migration and Mobility in an Enlarged Europe: a Gender Perspective. Leverkeusen: Barbara Budrich.

Miranda, A. (2008). Migrare al femminile. Milano: McGraw Hill.

Moch, L. P. (1992). Moving Europeans: Migration in Western Europe since 1650. Bloomington: Indiana University Press.

Morokvasic, M. (1983). Beyond the Reductionist Outlook, in: A. Phizacklea (ed.). One Way Ticket: Migration and Female Labour. London: Routledge and Kegan Paul, 13-31.

Morokvasic, M. (1984). Birds of passage are also women..., International Migration Review, 18 (4): 886-907.

Morokvasic, M. (1987). Jugoslawische Frauen: die Emigration - und danach. Stroemfeld: Roter Stern.

Morokvasic, M. (1991). Roads to Independence. Self-employed Immigrant and Minority Women in Five European States, International Migration, 19 (3): 407-420, doi: 10.1111/ j.1468-2435.1991.tb01028.x.

Morokvasic, M. (1993). In and Out of the Labour Market: Immigrant and Minority Women in Europe, New Community, 19 (3): 457-483. 
Morokvasic, M. (2004). Settled in Mobility: Engendering Post-wall Migration in Europe, Feminist Review, 77 (1): 7-25.

Morokvasic, M. (2007). Migration, Gender, Empowerment, in: I. Lenz, C. Ulrich and B. Fersch (eds). Gender Orders Unbound: Globalisation, Restructuring and Reciprocity. Opladen - Farmington Hills: Barbara Budrich, 69-97.

Morokvasic, M. (2011). L'(in)visibilité continue, Cahiers du genre (Migrantes et mobilisées), 51: $25-47$.

Ogaya, C. (2004). Social Discourses on Filipino Women Migrants, Feminist Review, 77 (1): $180-182$.

Oishi, Nana (2005). Women in Motion. Stanford: Stanford University Press.

Oso, L. (2003). The New Migratory Space in Southern Europe: The Case of Sex Workers in Spain, in: M. Morokvasic, U. Erel and K. Shinozaki (eds). Crossing Borders and Shifting Boundaries: Gender on the Move. Opladen: Leske und Budrich, 207-227.

Oso Casas, L. (2006). Prostitution et immigration des femmes latino-américaines en Espagne, Cahiers du Genre (Travail et mondialisation. Confrontations Nord / Sud, eds J. Falquet, H. Hirata and B. Lautier), 40: 91-114.

Parreñas, R. S. (2001). Servants of Globalization: Women, Migration and Domestic Work. Stanford: Stanford University Press.

Parreñas, R. S. (2008). The Force of Domesticity: Filipina Migrants and Globalization. New York: New York University Press.

Parreñas, R. S. (2011). Illicit Flirtations: Labor, Migration and Sex Trafficking in Tokyo. Stanford, CA: Stanford University Press.

Percot, M. (2005). Les infirmières indiennes émigrées dans les pays du Golfe : de l'opportunité à la stratégie, Revue européenne des migrations internationales, 21 (1): 29-54.

Pessar, P. R. and Mahler, S. J. (2003). Transnational Migration: Bringing Gender, International Migration Review, 37 (3): 812-846.

Pessar, P. (1984). The Linkage between the Household and the Workplace in the Experience of Dominican Immigrant Women in the United States, International Migration Review, 18 (4): 1188-1211.

Phizacklea, A. (ed.) (1983). One Way Ticket: Migration and Female Labour. London: Routledge and Kegan Paul.

Phizacklea, A. and Ram, M. (1996). Being Your Own Boss: Ethnic Minority Entrepreneurs in Comparative Perspective, Work, Employment E Society, 10 (2): 319-339, doi: 10.1177/0950017096102006.

Piper, N. (2003). Bridging Gender Migration and Governance: Theoretical Possibilities in the Asian Context, Asian and Pacific Migration Journal, 12 (1-2): 21-48.

Potot, S. (2005). La place des femmes dans les réseaux migrants roumains, Revue européenne des migrations internationales, 21 (1): 243-257.

Ramírez, A. (1999). La valeur du travail. L'insertion dans le marché du travail des immigrées marocaines en Espagne, Revue européenne des migrations internationales, 15 (2): 9-36.

Razy, É. and Baby-Collin, V. (2011). La famille transnationale dans tous ses états, Autrepart, 1 (57-58): 7-22, doi: 10.3917/autr.057.0007. 
Roulleau-Berger, L. (2010). Migrer au féminin. Paris: Presses universitaires de France.

Scheibelhofer, P. (2014). Integrating the Patriarch? Constructs of Migrant Masculinity in Times of Managing Migration and Integration, in: F. Anthias and M. Pajnik (eds). Contesting Integration, Engendering Migration. Basingstoke: Palgrave Macmillan, 185-201.

Shinozaki, K. (2015). Migrant Citizenship from Below: Family, Domestic Work and Social Activism in Irregular Migration. New York: Palgrave Macmillan (forthcoming).

Schwenken, H. (2006). Rechtlos, aber nicht ohne Stimme. Politische Mobilisierungen und irregulare Migration in die Europäische Union. Bielefeld: Transcript.

Schmoll, C. (2005). Pratiques spatiales transnationales et stratégies de mobilité des commerçantes tunisiennes, Revue européenne des migrations internationales, 21 (1): 131-154.

Scrinzi, F. (2005). Hommes de ménage, ou comment aborder la féminisation des migrations en interviewant des hommes, Migrations Société, 17 (99-100): 229-240.

Scrinzi, F. (2013). Genre, Migrations et Emplois Domestiques en France et en Italie: Construction de la Non Qualification et de L'altérité Ethnique. Paris: Editions Pétra.

Swaisland, C. (1993). Servants and Gentlewomen to the Golden Land: the Emigration of Single Women from Britain to Southern Africa, 1829-1939. Oxford - Providence: Berg University of Natal Press.

Tarrius, A. (1992). Les Fourmis d'Europe: Migrants riches, migrants pauvres et nouvelles villes internationales. Paris: L'Harmattan.

Tarrius, A., Missaoui, L. and Qacha, F. (2013). Transmigrants et nouveaux étrangers. Toulouse: Presses universitaires du Mirail.

Tienda, M. and Booth, K. (1991). Gender, Migration and Social Change, International Sociology, 6 (1): 51-72, doi: 10.1177/026858091006001004.

Thiévent, R. (2010). Temporal dimensions of cabaret dancers' circular migration to Switzerland, in: S. Kingston and K. Hardy (eds). New Sociologies of Sex Work. Aldershot: Ashgate, 149-165.

Triandafyllidou, A. (2013). Irregular Migrant Domestic Workers in Europe: Who Cares?. Aldershot: Ashgate.

Yuval-Davis, N. (1999). The 'multi-layered citizen': citizenship in the age of 'glocalization', International Feminist Journal of Politics, 1 (1): 119-136, doi: 10.1080/146167499360068. 


\section{Orodnjavanje migracija}

\section{Mirjana Morokvašić}

\section{SAŽETAK}

Migracijski obrasci, migracijski diskurs i s njima povezane reprezentacije, iskustva, obveze i dužnosti migranata kao i očekivanja od migracije rodno su obojeni. Otkako su feminističke znanstvenice koje se bave migracijama prve počele s propitivanjem muškaraca kao univerzalne reference i nevidljivosti žena ili njihova stereotipnog predstavljanja kao nesamostalnih u prevladavajućem korpusu znanja o migracijama, znanost se znatno razvila. $U$ radu se tvrdi da je stalni proces unakrsnog razvijanja u dvije odvojene epistemologije, a svaka je na početku propitivala monolitne i temeljne vizije »migranta $s$ jedne strane $\mathrm{i}$ »žene« $\mathrm{s}$ druge, otvorila plodno potpolje istraživanja »migracija i rod «. Slijedi pregled radova o orodnjavanju različitih faza migracije kako bi se pružio uvid $u$ ta istraživanja. Povezivanje migracija i roda dovelo je na vrh istraživačkih prioriteta i učinilo vidljivima teme koje su bile na marginama, pri čemu su izostavljene druge orodnjene dimenzije složene stvarnosti migrantskog iskustva.

KLJUČNE RIJEČI: migracija, rod, reprezentacija, državljanstvo, obitelj, utjecaj roda na migraciju, utjecaj migracije na rod 